\title{
ブタ大腸の破断強度の研究*
}

\author{
河 村 勇 太苂，苗 村

\section{Breaking Strength of Porcine Large Intestines} \\ Yuta KAWAMURA and Kiyoshi NAEMURA*3 \\ ${ }^{* 3}$ School of Bioscience and Biotechnology, Tokyo University of Technology, \\ 1404-1 Katakura-machi, Hachioji-shi, Tokyo, 192-0982 Japan
}

潔*2

\begin{abstract}
The colonoscope is widely employed for cure of a large intestinal disease. However, the medical accidents such as large intestines perforation by an immature doctor is still increase, because insertion operation of the colonoscope is highly skillful. To solve this problem, We think that development of a training device is effective. We aim to verify whether the porcine large intestines are able to become substitute as the human large intestines. The tensile experiment and the punch experiment were conducted on 243 samples of 14 pigs. The tensile experiment showed that stress at break was $0.20 \pm 0.08 \mathrm{MPa}$, and strain at break was $0.51 \pm 0.24$, and Young's modulus was $0.42 \pm 0.22$ $\mathrm{MPa}$, and the poisson ratio was $0.71 \pm 0.22$. Imitative endoscope extended the porcine large intestines forward perpendicular direction from the surface. The results showed the porcine large intestines were perforated by $11.9 \pm 2.8 \mathrm{~N}$. All results showed that porcine large intestines were able to become substitute of human large intestines.
\end{abstract}

Key Words: Medical Engineering, Biomechanics, Stress-Strain Measurement, Material Testing, Colonoscope, Large Intestines Perforation, Breaking Load

\section{1. 緒言}

大腸癌患者には高齢者が多いため, 体に負担の少な い内視鏡治療が求められている。大腸は S 状結腸と いう S 字状に彎曲し, 体内で可動性に富む腸管などか ら構成される。医師は先端を屈曲させ，本体を捻った りしながら内視鏡を大腸へ挿入する。挿入手技には熟 練を要し，末熟な医師の操作によって大腸に過剰な負 荷がかかり，大腸穿孔などの医療事故が後を絶たず， 死亡事故も起きている(1). 死亡事故の発生要因には, 医師が穿孔に気づかずに患者を放置してしまうことが ある. 既存の大腸内視鏡訓練装置には大腸穿孔が再現 されていない.そこで, 未熟な医師が大腸穿孔を体感 できる訓練用装置の開発が有効であると考える。本研 究では, ヒト大腸の代替としてのブタ大腸の有効性を 引張試験と穿孔実験から検証することを目的とした。

\section{2. ブタ大腸の前処理方法}

食肉処理場より生後 $6 \sim 7$ ヶ月齢のブタ大腸を購入

\footnotetext{
* 原稿受付 2009 年 2 月 12 日.

*1 学生員, 東京工科大学大学院バイオ・情報メディア研究科 (更192-0982 八王子市片倉町 1404-1).

*2 正員, 東京工科大学応用生物学部。

E-mail : nae@bs.teu.ac.jp
}

し，乾かないようにビニール袋，または発泡スチロー ル容器に入れて実験室まで搬送した。本実験では全て 以下のように同様の前処理を施している。まず，余分 な脂肪や腸間膜を除去して一本の七モ状にした，次に 肚門側から $200 \mathrm{~mm}$ 間隔に切り分けし, 肛門からの距 離が $400 \mathrm{~mm}$ から $1600 \mathrm{~mm}$ までの部位を直腸側結 腸, $1600 \mathrm{~mm}$ から $2800 \mathrm{~mm}$ までの部位を中間部結 腸, $2800 \mathrm{~mm}$ から $4000 \mathrm{~mm}$ までの部位を盲腸側結 腸とした。また，穿孔実験のように規格にはない実験 を行うため，結腸七モを境に切り分けて $200 \mathrm{~mm} \times 30$ $\mathrm{mm}$ の短冊状にし，譬のない状態に処理した。前処理 を施した大腸は各部位毎にケースに入れ，濃度 $0.9 \%$ の生理食塩水に浸漬して保存した。

\section{3. 引 張 試 験}

$3 \cdot 1$ 方法 大腸の固定は規格で決められた方法 がないために試行錯誤の結果，大腸の両端を鉗子で固 定する方法を採用した。鉗子による応力集中を防ぎ， 大腸の水分を吸収して固定を確実に行うために，鉗子 と大腸との間に $70 \mathrm{~mm} \times 30 \mathrm{~mm}$ のダンボール紙を挟 み込んだ。次に，大腸を固定した鉗子の取っ手を点滴 スタンドに掛けて大腸を吊るした，もう一方の鉗子の

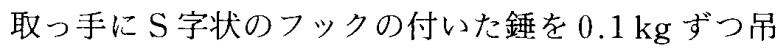


るしていき, 初期長さ $L_{0}[\mathrm{~mm}]$, 幅 $b_{0}[\mathrm{~mm}]$ に対し て, 質量 $m[\mathrm{~kg}]$ のとの重力方向の長さ $L_{1}[\mathrm{~mm}]$ と 幅 $b_{1}[\mathrm{~mm}]$ を記録した。それぞれの荷重に対する伸 びを正確に测定するため, 鉗子に吊るす鏵は重さを変 えるごとに一旦外してから新たな重さの鍾を加えるよ うにした。また，錘は鉗子に静かに吊るした，大腸の 厚さが $1 \mathrm{~mm}$ 均一であると考え, 応力 $\sigma$, 縦ひずみ $\varepsilon$, 横ひずみ $\varepsilon \perp$ を求めた。また, $\varepsilon と \varepsilon \perp$ の比からポア ソン比を算出した.

$$
\begin{aligned}
& \sigma=\frac{m g}{b_{0}} \ldots \ldots \\
& \varepsilon=\frac{L_{1}-L_{0}}{L_{0}} \\
& \varepsilon \perp=\frac{b_{1}-b_{0}}{b_{0}}
\end{aligned}
$$

$3 \cdot 2$ 結果 ブタ 3 頭分から切り出した 48 サンプ ルの大腸に対して引張試験を行ったときの破断応力は $0.20 \pm 0.08 \mathrm{MPa}$ であり, 破断時のひずみは $0.51 \pm$ 0.24 であった。また, 応力 $\sigma$ とひずみ $\varepsilon$ の関係(図 1) から,ブタ大腸のヤング率は $0.42 \pm 0.22 \mathrm{MPa}$ であっ た。また, 図1のように降伏点は確認出来なかった。 ブタ大腸のポアソン比は $0.71 \pm 0.22$ であった。表 1 , 表 2 に直腸側, 中間部, 盲腸側結腸の部位別の破断応 力, 破断ひずみ, ヤング率, ポアソン比を示す. 多重 比較検定 (Tukey-test) の結果, 直腸側と中間部の破 断応力值に $p<0.05$, 直腸側と盲腸側の破断応力值に $p<0.01$ の有意差を認め,さらに中間部と盲腸側につ いてはヤング率においても $p<0.05$ の有意差を認め た。

$3 \cdot 3$ 考察 山田ら ${ }^{(2)}$ は $70 \cdot 80$ 歳代のヒト大腸の 引張り強さは $0.33 \mathrm{MPa}$ と報告しており, 大腸の部位 別についてみると上行結腸は $0.41 \mathrm{MPa}$, 横行結腸は $0.33 \mathrm{MPa}$ ，下行結腸は $0.24 \mathrm{MPa}$ であった。 また，他 の実験動物としてよく用いられるイヌの大腸の引張り 強さは $0.91 \mathrm{MPa}$ であった. 本引張試験で得たブ夕の 引張り強さは $0.20 \mathrm{MPa}$ であった。これはイヌよりも

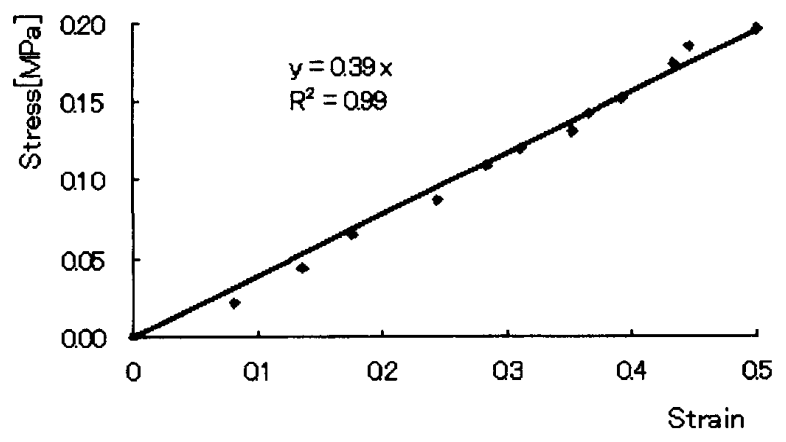

Fig. 1 One example of stress ${ }^{-}$strain measurement
ブタの方がヒト大腸の代替と成り得ることを示してお り，特にヒト大腸の下行結腸と同等の引張り強さであ ると言える.Viacheslavら(3) の報告によると，死体 標本から得られたヒト大腸のヤング率は $0.50 \mathrm{MPa} て ゙$ あった. ブタ大腸のヤング率がヒト大腸より小さい理 由として, 動物種の違いということの他にも被検体の 成熟度の違いが考えられる. 山田ら(2) は老化と共に 大腸の伸びも小さくなると報告している. Viaches$\mathrm{lav}$ らのヒトの被検体 46 例の平均年齢は $55 \pm 8.5$ 歳 であり，完熟に達していた。これに対し，本実験で用 いたブ夕は平均 6〜7ヶ月齢であり, まだ完熟には達 していない。 また，大腸の保存法についてもViaches$\operatorname{lav}$ らの実験では，検死の前に $4^{\circ} \mathrm{C} て ゙$ 保存され，器官部 分は洗浄された後に再び $4^{\circ} \mathrm{C} て ゙$ 生理食塩水に保たれて いた。本実験では常温の生理食塩水で保存した。これ らの被検体の完熟度や保存液の温度の違いが実験値に 影響を及ほしたものと考えられる。

\section{4. 穿 孔実 験}

4・1 方法 1 軸方向に移動する自動ステージ (SGSP 26-50, シグマ光機)の上に突き方向の軸力を 計測する定格負荷 $100 \mathrm{~N}$ の反力センサ (LMC-21023,

Table 1 Result of each part of tension experiment

\begin{tabular}{c|c|c}
\hline & $\begin{array}{c}\text { Stress at } \\
\text { break [MPa] }\end{array}$ & Strain at break \\
\hline $\begin{array}{c}\text { Rectum side } \\
(15 \text { sample) }\end{array}$ & $0.25 \pm 0.08$ & $0.47 \pm 0.17$ \\
$\begin{array}{c}\text { Intermediate } \\
\text { part } \\
(19 \text { sample })\end{array}$ & $0.17 \pm 0.08$ & $0.47 \pm 0.20$ \\
$\begin{array}{c}\text { Caecum side } \\
(14 \text { sample })\end{array}$ & $0.15 \pm 0.04$ & $0.64 \pm 0.31$ \\
\hline $\begin{array}{c}\text { All sample } \\
(48 \text { sample })\end{array}$ & $0.20 \pm 0.08$ & $0.52 \pm 0.24$ \\
\hline
\end{tabular}

Table 2 Result of each part of tension experiment

\begin{tabular}{c|c|c}
\hline & $\begin{array}{c}\text { Young's modulus } \\
{[\mathrm{MPa}]}\end{array}$ & $\begin{array}{c}\text { Poisson' s } \\
\text { ratio }\end{array}$ \\
\hline $\begin{array}{c}\text { Rectum side } \\
(15 \text { sample })\end{array}$ & $0.51 \pm 0.21$ & $0.78 \pm 0.30$ \\
$\begin{array}{c}\text { Intermediate } \\
\text { part } \\
(19 \text { sample })\end{array}$ & $0.39 \pm 0.24$ & $0.60 \pm 0.14$ \\
$\begin{array}{c}\text { Caecum side } \\
(14 \text { sample })\end{array}$ & $0.27 \pm 0.14$ & $0.81 \pm 0.14$ \\
\hline $\begin{array}{c}\text { All sample } \\
\text { (48sample) }\end{array}$ & $0.42 \pm 0.22$ & $0.71 \pm 0.22$ \\
\hline
\end{tabular}




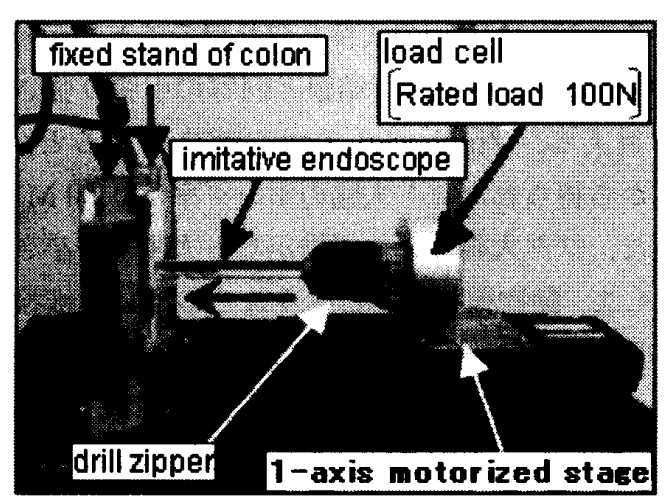

Fig. 2 Experimental setup

日章電機)を固定した。反力センサにはドリルチャッ ク（LF 10，ユキワ精工）を取り付け，実験に使用する 模擬内視鏡を固定した (図 2)。模擬内視鏡には直径 10 $\mathrm{mm}$ の角を面取りしたアクリル円柱を使用した。大 腸固定台の間隔を $70 \mathrm{~mm}$ とし, 大腸の両端を $2 つ 0$ 鉗子で二重に交差するように把持固定した。鉗子と大 腸との間に引張試験と同様にダンボール紙を挟み込ん だ.ステージ移動速度を $20 \mathrm{~mm} / \mathrm{s}$ に設定し, 初期位 置から大腸穿孔するまで移動させ続け，破断確認後に 初期位置へと戻した。サンプリング周波数を $40 \mathrm{~Hz}$ としてデータレコーダ $(8807$, 日㯰電機)に反力を記録 した．穿孔破断したときの反力の值と，それを模擬内 視鏡の断面積で割った值を求めた.

$4 \cdot 2$ 結果 ブタ 8 頭分から切り出した 122 サン プルの大腸に対して 40 から $50 \mathrm{~mm}$ の伸展の後に穿

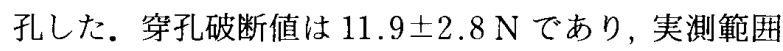
は $6.5 \mathrm{~N}$ から $18.6 \mathrm{~N}$ であった。表 3 に穿孔破断值の 部位別の比較を示す. 多重比較検定の結果, 統計学的 な有意差は認められなかった。

$4 \cdot 3$ 考察 宇野ら ${ }^{(4)}$ はヒト大腸の摘出標本に対 して圧烈強さを穿孔破断の測定を実施しており, 内視 鏡先端部の断面積から七ト大腸の破断応力を求めた. その結果, 大腸内視鏡による応力範网が $0.29 \mathrm{MPa}$ 以 上になると穿孔破断が起きる危険性が高いとしてい る. 本実験で得た結果を模擬内視鏡の断面積 $(78.5$ $\mathrm{mm}^{2}$ )で割ると $0.15 \pm 0.04 \mathrm{MPa}$ であり，ヒト大腸の
Table 3 Result of each part of boring experiment

\begin{tabular}{c|c}
\hline & Load at perforation [N] \\
\hline $\begin{array}{c}\text { Rectum side } \\
(47 \text { sample })\end{array}$ & $12.2 \pm 2.8$ \\
$\begin{array}{c}\text { Intermediate part } \\
(45 \text { sample })\end{array}$ & $11.3 \pm 2.6$ \\
$\begin{array}{c}\text { Caecum side } \\
(25 \text { sample })\end{array}$ & $12.1 \pm 2.7$ \\
\hline $\begin{array}{c}\text { All sample } \\
(122 \text { sample })\end{array}$ & $11.9 \pm 2.9$ \\
\hline
\end{tabular}

破断応力よりも小さい值となった。ヒト大腸よりも小 さな負荷で破断を起こすことから，より効率的な技術 向上にブタ大腸を用いることができると考える。

\section{5. 結 語}

大腸穿孔を体感できるような訓練用装置に用いるヒ ト大腸の代替としてブタ大腸の応用可能性を検証する ため, 引張試験と穿孔実験から引張り強さ, ヤング率 などを求めて大腸強度の文献值と比較した。その結 果，ブタ大腸はヒト大腸の代替物とすることで，より 効果的な挿入練習が出来ることを示した。

本研究を進める上で, 外科医である篠原一彦先生 (東京工科大学)に御助言を頂いた。また，実験は石河 剛史君，向井智将君の協力のもと実施した。

$$
\text { 文献 }
$$

(1) Kaneko, E., Harada, H., Kasugai, T., Ogoshi, K. and Tanba, H., The 4th nationwide investigation report concerning syndrome of happening by accident related to gastroenterological endoscopy-Five years from 1998 to 2002, Gastroenterolocal Endoscopy, Vol. 46, No. 1 (2004), pp. 54-61.

(2) Yamada, H., Strength and aging of human body, Japan Broadcasting Corporation, (1979), pp. 108-116.

(3) Egorov, V. I., Schastlivtsev, I. V., Prut, E. V., Baranov, A. O. and Turusov, R. A., Mechanical properties of the human gastrointestinal tract, $J$. Biomech., Vol. 35, No. 10 (2002), pp. 1417-1425.

(4) Uno, Y., Minute diameter colonoscope $\cdot$ Examination of safety of CF-SV, Japanese Society of Medical Instru. mentation, Vol. 67, No. 7 (1997), pp. 289-292. 